\section{S. Barnard \\ B. Kritzinger \\ J. Krüger}

\title{
LOCATION DECISION STRATEGIES FOR IMPROVING SMME BUSINESS PERFORMANCE
}

\author{
Ms Shereen Barnard, Nelson Mandela Metropolitan University \\ Ms Barendien Kritzinger, Nelson Mandela Metropolitan University \\ Ms Janine Krüger, Nelson Mandela Metropolitan University
}

\begin{abstract}
Purpose: The primary objective of this study is to investigate the macro-environmental factors that may influence location decisions and how these choices may affect the business performance of SMMEs.

Problem investigated: SMMEs in South Africa play an increasingly important role in stimulating economic activity, growth and employment creation. However, many SMMEs cease to exist within the first five years of operation due to various challenges faced by SMMEs on a daily basis. Many SMMEs owners disregard the importance of location, yet the geographical location can negatively influence the survival of the business. Several factors influence the choice of the location, which will ultimately have either a positive or negative effect on business performance.
\end{abstract}

Methodology: A positivistic research methodology was adopted for this study. Seven hypotheses were constructed to achieve the primary objective of this study. The population for this study consisted of SMMEs in the Nelson Mandela Metropole from which a convenience sample of 175 SMMEs was selected. The measuring instrument, a self-developed questionnaire, consisted of three sections. The data collected included the demographical data of the respondents and their businesses, statements on location and various factors influencing location decisions as well as measurements of business performance. Cronbach Alpha coefficients were calculated to determine the reliability of the questionnaire items. Data analysis was done by calculating descriptive statistics, Pearson correlation coefficients and conducting a simple linear regression analysis. Cohen's d was used to determine the significance of between-factor differences.

Findings and implications: The results of the study showed that positive relationships existed between all the independent variables (location, rental rates, employment, inflation, interest rates and green buildings) and the dependent variable (business performance) except for the relationship between electricity tariffs and business performance. Employment and business performance attained the strongest positive relationship; indicating that business owners regarded employment as an important factor to consider when searching for suitable business premises. The relationship between location and business performance obtained the lowest positive correlation.

Originality and value of the research: Research on South African SMMEs regarding location decisions and the specific factors identified in this study has not been done previously in South Africa. Therefore, because evidence exists that the macroenvironmental factors influence location decisions to varying degrees, this study can provide SMME owners with insight into the factors influencing location choice. It is vital that business owners consider these factors as they could influence business performance, and ultimately, business survival. An increased awareness of the importance of the aspects discussed in this study could consequently lead to improved performance in the SMME sector.

Keywords and phrases: SMMEs, location, business performance.

\section{INTRODUCTION}

Small, micro and medium enterprises (SMMEs) are of great importance to the economy as they stimulate economic activity and growth and create job opportunities in all sectors of the market. This emphasises the high labour absorption characteristic of small businesses, suggesting that they produce wealth at a faster pace than larger businesses (Abor \& Quartey, 2010:218; Elliott \& Boshoff, 2007:15). Many start-up businesses initially operate from informal premises, such as the owner's home, and gradually grow and 


\section{S. Barnard \\ B. Kritzinger \\ J. Krüger}

LOCATION DECISION STRATEGIES FOR IMPROVING SMME BUSINESS PERFORMANCE

expand until there is a need to relocate to larger premises that is usually more formal in nature (Bosch, Tait \& Venter, 2011:580). This provides additional employment opportunities.

SMMEs contribute an estimated $52 \%$ to $57 \%$ to the Gross Domestic Product (GDP) in South Africa and provide approximately $61 \%$ to employment. The majority of workers $(73 \%)$ are employed by businesses with less than 50 employees, and $45 \%$ of all employed people work in businesses with less than ten employees. These businesses also comprise about 91\% of formal business entities (Abor \& Quartey, 2010:223; 'Small business', 2009:3). Elliott and Boshoff (2007:15) and Olawale and Garwe (2010:729) found that for small business development it is vital in emerging economies, such as in South Africa, to attend to problems of unemployment and low economic growth and to the negative impact such problems have on social development. According to the Global Entrepreneurship 2010 Global Report (Kelley, Bosma \& Amorós, 2011:25), the growth rate of businesses in existence less than three and a half years has increased since 2009.

Although SMMEs stimulate economic growth and job creation in South Africa, they still face a number of challenges that affect their business performance and ability to realise their full potential. If these challenges are not managed efficiently, it could ultimately lead to business failure. In general, younger businesses have a higher failure rate than older and more established businesses. In South Africa, about $57 \%$ of small businesses fail within the first year of conducting business, while $70 \%$ to $80 \%$ of all new small businesses fail within the first five years (Bosch et al., 2011:594; Scarborough \& Zimmerer, 2003:26; Sha, 2006:35). This sentiment of high failure rates of small businesses is shared by Roberts (2010) who states that approximately $63 \%$ of small businesses in South Africa fail within the first two years of operation.

Some challenges specifically facing SMMEs in South Africa have been identified and include the following: lack of managerial competence and skill, difficulty in gaining access to technology, limited access to finance, scarce resources, poor location decisions, high start-up costs, complex legal and regulatory requirements and low barriers to entry (Abor \& Quartey, 2010:224; Bosch et al., 2011:594; Sha, 2006:52). Another important issue that all business face is that of fraud and corruption. If one considers the Ernst \& Young Summer Survey (2010), Swiss SMMEs regard the strong economic growth of Brazil, Russia, India and China as opportunities for their own expansion. The research found that $34 \%$ of the respondents that participated in the study indicated that corruption is a major issue when conducting business in Russia.

By being aware of these potential challenges, business owners can implement principles and measures to effectively control and even avoid these issues. Therefore, business owners should be forewarned and proactive in their decision making and managing of the daily operations of the business (Bosch et al., 2011:594). Walters (2011a) and Campbell (2008) agree that business owners should be aware of the impact the location has on the business because it can make the difference between failure and success. The business owners should consider the type of products sold, that is, whether it is convenience products, speciality products or shopping products. Walters (2011b) also provides a number of tips for when considering various locations. The tips involve careful consideration of the population and the potential customers of the business; the accessibility and visibility of the business; the zoning of the location and future planning of that location area; the competition and other businesses at the location; the location costs; personal factors; and other special considerations, such as special requirements, parking lot, crime rate and governmental restrictions and laws.

Olawale and Garwe (2010:731) define a business environment as all those factors, both internal and external to the business, that may influence the survival of the business. The developments and changes that have recently taken place in the business environment, such as globalisation, increased competitive pressure, information technology and the focus on value creation, have forced businesses to take additional measures 


\section{S. Barnard \\ B. Kritzinger \\ J. Krüger}

LOCATION DECISION STRATEGIES FOR IMPROVING SMME BUSINESS PERFORMANCE

to gain a competitive advantage in the market. Because of this demanding business environment, businesses are being pressurised to adopt more effective control procedures to ensure efficient business functioning. One key procedure is the implementation of a performance measurement system (Perera \& Baker, 2007:10).

According to Perera and Baker (2007:10), performance measurements may include techniques such as an economic value-added (EVA) approach and a market value-added (MVA) approach. A second measure is to place greater emphasis on the importance of non-financial performance measurements and adding value to clients and other stakeholders. Business performance is influenced by both quantitative and qualitative factors and represents both financial and non-financial aspects of the business's performance. Some financial aspects used to measure business performance include sales revenue, profitability, sales growth, cash flow, cost reduction, return on investment and market share. It is important to note that if customers buy on credit, it will have an influence on the cash flow of the business. Another issue that then arise is the nonpayment of accounts by customers; this is also of great concern to businesses especially during financially difficult situations such as recessions (Megginson, Smart \& Graham, 2010:738-751). On the other hand, some non-financial aspects include factors like product quality, productivity, customer requirements, responsiveness, the quality of suppliers, the efficiency of production processes, innovativeness as well as the quality and performance of employees (Perera \& Baker, 2007:13,18; Vos \& Roulston, 2008:71).

A well-established SMME usually grows in size and capacity and often requires the assistance of a manager in the running of the day-to-day operations. Perera and Baker (2007:20) found that these non-owner managers generally make greater use of non-financial performance measures when measuring business performance, whereas owner-managers generally implement financial measures when measuring performance (Burke, Clarke, Molian \& Barrow, 2008:125; Perera \& Baker, 2007:15, 23; Vos \& Roulston, 2008:71). Thus, it is evident that SMMEs continue to place greater emphasis on financial measures and fail to see the benefits of using non-financial measures.

\section{OBJECTIVES OF THE STUDY}

The primary objective of this study is to identify and investigate the predetermined macro-environmental factors that may influence location decisions of business owners. These may well affect the business performance of SMMEs in the Nelson Mandela Metropole where business performance is measured by changes in net profit after tax, return on total assets, annual sales, operating costs, productivity, employment growth and turnover.

In order to give effect to the primary objective, the following secondary objectives were explored:

- To investigate literature on SMMEs, the South African economy and business performance.

- To determine the macro-environmental factors that may influence business owners' decisions in finding the most suitable business premises.

- To investigate empirically whether relationships exist between the location decision factors (independent variables) and business performance (dependent variable).

- To give recommendations to business owners on the importance of managing these factors by providing possible strategies that can be followed.

\section{PROBLEM INVESTIGATED}

When searching for the ideal property, business owners should consult a marketing consultant to gather information relating to the various properties available. Once property choices have been identified, business owners should evaluate each of these properties to ensure that satisfactory business performance can be 


\section{S. Barnard \\ B. Kritzinger \\ J. Krüger}

LOCATION DECISION STRATEGIES FOR IMPROVING SMME BUSINESS PERFORMANCE

expected from the chosen business premises. Various macro-environmental factors will influence the choice of the most appropriate property.

As research suggests, see for example Cuss (2003:277) and Heckaman (2008:12-14), there are a number of macro-environmental factors that will influence the decision-making processes of business owners. Some of these factors include location, rental rates, electricity tariffs, employment, inflation, interest rates and green buildings. Any individual factor, or combination thereof, can influence the business owner's location decision - regarding the best location - in varying degrees, according to the state of the economy at the time of purchase. Business owners are able to control where their business property is located, but they are not in control of the macro-environmental factors that influence these location decisions.

Each business type (office, retail and industrial) has different location requirements and therefore the nature of the business should be taken into consideration when locating a suitable site. The site availability and costs of the commercial property also influence where the business will be located as well as the potential market, customer accessibility and the availability and proximity of resources (Bosch et al., 2011:220-227, 230-233). Each type of property offers different rental levels as a result of supply and demand in the property market. Office buildings are categorised according to four different grades, namely Grade P, Grade A, Grade $B$ and Grade C, ranging from superior benefits and features to basic and standardised features (Heckaman, 2008:12; Petersen, 2010:58). Each location's profit potentials differs based on the nature of the business activities, which influence the amount owners are prepared to pay for the property. Thus, the willingness and ability to pay will determine whether to purchase or rent a property (Ball, Lizieri \& MacGregor, 2001:14).

Based on the property type and nature of the business, the electrical system requirements for commercial property differ. Business owners should ensure that the property and building comply with the electrical health and safety regulations (Dufaye, 2005). Electricity is one of the largest operating expenses for commercial properties, and business owners can implement various cost-saving initiatives through the efficient use of lighting, maintenance and energy control. These initiatives can safeguard the business from future electricity tariff hikes and avoid passing the costs on to consumers. However, the implementation of energy-efficient systems is not always an option for SMMEs because of the high initial capital outlay. Therefore, business owners can benefit from cost savings by searching for business premises that already have these electrical energy-efficient systems in place (Berry, 2010; Butler \& Jack, 2010).

The physical characteristics of the workplace and the productivity of the employees are positively correlated. The productivity of employees can be improved through the efficient and effective organisation of teams and by supporting the emotional well-being of the employees using rewards and creating a sense of security and belonging (Best, Langston \& De Valence, 2003:6). Business owners should ensure that the building and work environment comply with the standards of health, safety and welfare by providing adequate workplace facilities. A combination of motivated employees and increased productivity may ultimately enhance business performance (Booty, 2009:12).

Inflation rates affect the rent paid by tenants and the income received by landlords. When vacancy rates are low, landlords have the power to charge higher rental rates with increasing inflation; however, when vacancy rates are high, the negotiating power switches to tenants, who then have the ability to choose cheaper alternatives, regardless of inflation rates. In general, the price of products and services increases as the inflation rate increases, and thereby diminishes consumers' purchasing power. This reduces the demand for products and services resulting in lower revenues for business owners (Ebazaar, 2008; Hartzell \& Webb, 1993). 


\section{S. Barnard \\ B. Kritzinger \\ J. Krüger}

Bosch et al. (2011:62) describe the interest rate as the cost of money expressed as a percentage. The demand for and supply of money in the market determines the level of the interest rate at a given period of time. Changes in interest rates, such as the repo rate and the prime lending rate, influence the costs related to purchasing or leasing a property. An increase in interest rates makes purchasing a property more expensive for business owners as the cost associated with a mortgage bond will be higher than the cost of renting ('How the interest rate cut', 2010; Kernohan, 2010).

"Green buildings" are a growing trend in the commercial property market as the long-term cost-saving benefits are attractive. These buildings operate efficiently through the effective use of energy, materials, water, building site and design (Mungoshi, 2008). The Department of Minerals and Energy (DME) published the SANS (South African National Standards) 204 in order to achieve energy efficiency in the building sector. It is a proactive shift towards reducing energy consumption and the related costs for individuals, and helping to ensure that the energy available to South Africa is sustained (Naidoo, 2008). As the SANS regulations are currently voluntary but are soon to be compulsory, business owners should consider implementing green building principles.

Therefore, this study will address the factors concerning location decisions in SMMEs. To conclude, the problem statement for this study can be described as follows:

To determine strategies that can be employed by SMMEs to improve business performance in the Nelson Mandela Metropole.

\section{HYPOTHESES}

Seven null $\left(\mathrm{H}_{0,1}-\mathrm{H}_{0,7}\right)$ and seven alternative $\left(\mathrm{H}_{1,1}-\mathrm{H}_{1,7}\right)$ hypotheses were constructed in order to give effect to the problem statement, namely to determine whether relationships exist between the independent variables (location, rental rates, electricity tariffs, employment, inflation, interest rates and green buildings) and the dependent variable (business performance). Based on the literature review, the following null hypotheses $\left(\mathrm{H}_{0,1}-\mathrm{H}_{0,7}\right)$ were constructed and tested in the empirical investigation:

$\mathrm{H}_{0,1}$ - No relationship exists between location and business performance.

$\mathrm{H}_{0,2}-$ No relationship exists between rental rates and business performance.

$\mathrm{H}_{0,3}$ - No relationship exists between electricity tariffs and business performance.

$\mathrm{H}_{0,4}$ - No relationship exists between employment and business performance.

$\mathrm{H}_{0,5}$ - No relationship exists between inflation and business performance.

$\mathrm{H}_{0,6}$ - No relationship exists between interest rates and business performance.

$\mathrm{H}_{0,7}$ - No relationship exists between green buildings and business performance.

The alternative hypotheses $(\mathrm{H} 1,1-\mathrm{H} 1,7)$ are stated as the opposite of the null hypotheses:

$\mathrm{H}_{1,1}$ - A relationship exists between location and business performance.

$\mathrm{H}_{1,2}-\mathrm{A}$ relationship exists between rental rates and business performance.

$\mathrm{H}_{1,3}-$ A relationship exists between electricity tariffs and business performance.

$\mathrm{H}_{1,4}-\mathrm{A}$ relationship exists between employment and business performance.

$\mathrm{H}_{1,5}$ - A relationship exists between inflation and business performance.

$\mathrm{H}_{1,6}$ - A relationship exists between interest rates and business performance.

$\mathrm{H}_{1,7}-\mathrm{A}$ relationship exists between green buildings and business performance. 


\section{S. Barnard \\ B. Kritzinger \\ J. Krüger}

LOCATION DECISION STRATEGIES FOR IMPROVING SMME BUSINESS PERFORMANCE

From theory it is evident that the seven macro-environmental factors influence the location decisions of business owners. Therefore, based on the above, a hypothetical model (see Figure 1) was developed and this study focused on determining whether relationships exist between these predetermined macroenvironmental factors and business performance.

Figure 1: Seven independent variables affecting business performance

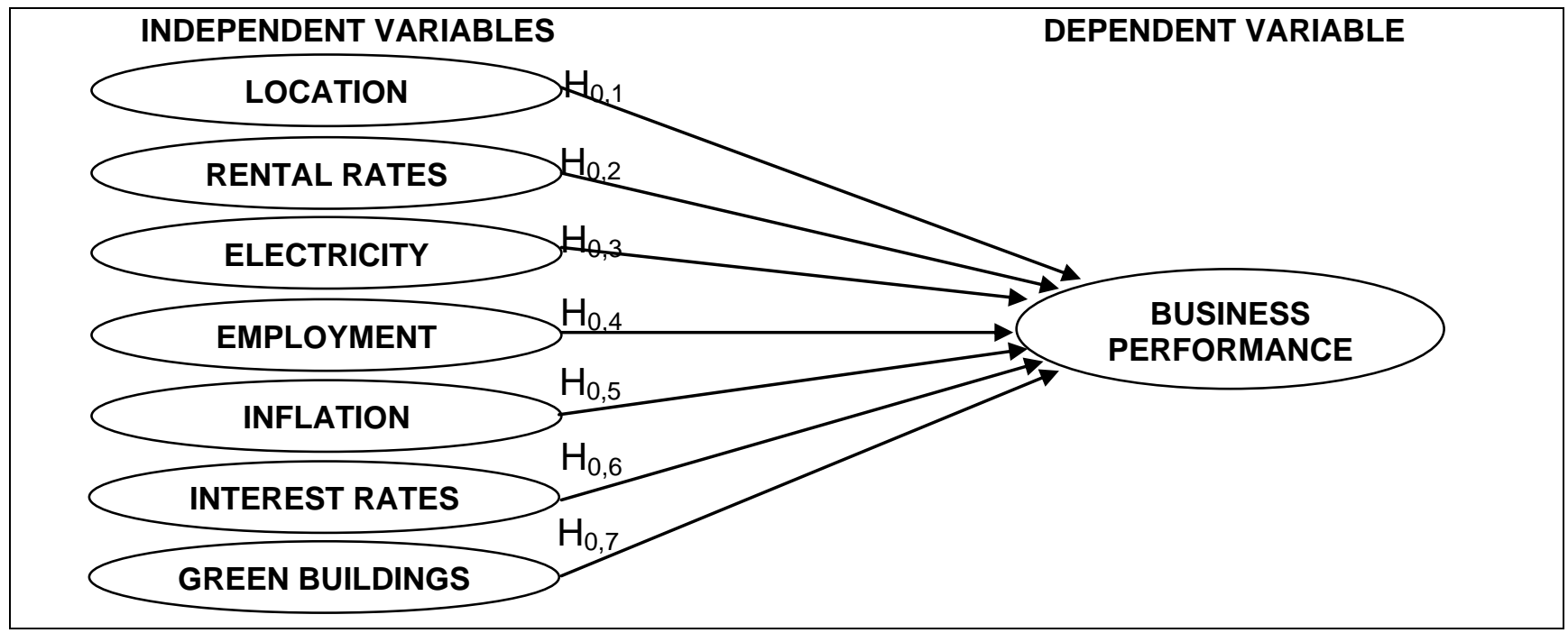

\section{RESEARCH METHODOLOGY}

Given the nature of the problem statement and research objectives of this study, a positivistic paradigm was adopted as it makes use of a scientific quantitative research method (Burns \& Burns, 2008:13). Quantitative research is an objective, obtrusive and controlled measurement involving large representative samples and fairly structured data collection procedures. The primary role of this approach is to test hypotheses derived from a theoretical proposal (Lancaster, 2005:66-67; Struwig \& Stead, 2001:4).

Secondary and primary sources were used to collect data for this study. The secondary sources consulted were websites, including online newspapers and magazines, articles in journals and academic books. A fivepoint Likert-type scale questionnaire was constructed in order to collect primary data. The objective of the questionnaire was to investigate the macro-environmental factors that may influence location decisions and hence the performance of SMMEs.

The population for this study represented business owners/managers of SMMEs in the Nelson Mandela Metropole and the target sample was selected from this population. Convenience sampling was used to select 175 SMMEs that were conveniently available. The data was collected in the period June to July 2010.

Special attention was given to the issues of validity and reliability when the items of the questionnaire were formulated. According to Struwig and Stead $(2001: 136,139)$, validity is the extent to which a scale or testing instrument is scientifically sound or appropriately conducted. Face and content validity were employed to ensure that the test scores were valid for the sample being tested. Reliability is the stability or consistency of a measurement; in other words, it refers to the degree to which the measure is stable and yields consistent 


\section{S. Barnard \\ B. Kritzinger \\ J. Krüger}

numerical results each time it is applied (De Vos, Strydom, Fouché \& Delport, 2005:162-163). The Cronbach Alpha coefficient was calculated in order to assess the internal reliability of all items in the questionnaire.

A number of statistical methods were used to analyse the primary data gathered from the questionnaires in order to test the hypotheses constructed. The mean, standard deviation and Cohen's $\mathrm{d}$ were the descriptive statistical methods used to summarise and analyse the data collected. Descriptive statistics involve the collection, presentation, summarisation and description of data so that a simple representation of a large amount of data can be comprehended (Burns \& Burns, 2008:8).

Inferential statistics are used to draw conclusions about a population on the basis of the sample (Zikmund, 2006:402). The Pearson correlation coefficient $(r)$ was computed to determine the degree of relationship between the two variables (De Vos et al., 2005:241; Hair, Babin, Money \& Samouel, 2003:283). To determine the strength of a relationship, the coefficient of determination $\left(r^{2}\right)$ was used: It is a measure of that portion of the total variance of a variable (independent variable) that is accounted for by knowing the value of another variable (dependent variable) (Zikmund, 2006:555). Thus, simple linear regression was a technique used to measure the linear association between the seven independent variables and the dependent variable (Zikmund, 2006:551).

\section{RESULTS}

In order to test whether relationships exist between the independent variables (location, rental rates, electricity tariffs, employment, inflation, interest rates and green buildings) and the dependent variable (business performance), an empirical investigation was conducted. The results of this investigation are summarised below.

\section{Demographical data of respondents and their businesses}

As indicated in Table 1, the majority of the respondents were white males between the ages of 40 and 49 years and were both the manager and owner of the business. It should be noted that $1 \%$ of the respondents were not willing to disclose the ethnic group they belonged to. In addition, the majority of the respondents have been working for more than 20 years and were employed in their current place of work for between three and five years.

The percentage distribution of the population by population group and province for the Eastern Cape Province is the following: $4.7 \%$ of the population are classified as white, $87.6 \%$ as black African, $7.5 \%$ as coloured and $0.3 \%$ as Asian (Statistics South Africa, 2007:25). Table 1 indicated that the majority of the respondents are from the white population group. One possible reason for this high ratio can be that $96 \%$ of the rural households are African households and that the Eastern Cape Province comprises of many rural areas (Statistics South Africa, 2006:8).

The age distribution of the respondents is in line with the findings of Statistics South Africa (2007:63); the findings of Statistics South Africa (2007:63) also indicated that in the Eastern Cape the distribution between male and female is $47 \%$ and $52 \%$ respectively. 
S. Barnard

B. Kritzinger

J. Krüger
LOCATION DECISION STRATEGIES FOR IMPROVING SMME BUSINESS PERFORMANCE

Table 1: Demographical data of respondents

\begin{tabular}{|c|c|c|c|}
\hline \multicolumn{2}{|l|}{ Items } & Frequency & Percentage (\%) \\
\hline \multirow{4}{*}{ Gender } & Male & 91 & 52 \\
\hline & Female & 83 & 47 \\
\hline & Missing & 1 & 1 \\
\hline & Total & 175 & 100 \\
\hline \multirow{7}{*}{ Age } & $<20$ & 0 & 0 \\
\hline & $20-29$ & 28 & 16 \\
\hline & $30-39$ & 45 & 26 \\
\hline & $40-49$ & 54 & 31 \\
\hline & $50-59$ & 39 & 22 \\
\hline & $60+$ & 9 & 5 \\
\hline & Total & 175 & 100 \\
\hline \multirow{7}{*}{ Population group } & Asian & 5 & 3 \\
\hline & Black & 5 & 3 \\
\hline & Coloured & 9 & 5 \\
\hline & White & 150 & 86 \\
\hline & Other & 4 & 2 \\
\hline & Not willing to say & 2 & 1 \\
\hline & Total & 175 & 100 \\
\hline \multirow{5}{*}{ Occupational level } & Manager & 36 & 21 \\
\hline & Owner & 39 & 22 \\
\hline & Both manager and owner & 97 & 55 \\
\hline & Missing & 3 & 2 \\
\hline & Total & 175 & 100 \\
\hline \multirow{7}{*}{$\begin{array}{l}\text { Total working } \\
\text { experience (years) }\end{array}$} & $0-2$ & 1 & 1 \\
\hline & $3-5$ & 9 & 5 \\
\hline & $6-9$ & 15 & 9 \\
\hline & $10-19$ & 48 & 27 \\
\hline & $20+$ & 87 & 50 \\
\hline & Missing & 15 & 8 \\
\hline & Total & 175 & 100 \\
\hline
\end{tabular}

It was also found, as shown in Table 2, that the bulk of the respondents' businesses had been in operation for between 10 and 19 years. Most of the respondents leased their business premises and occupied both retail and office space. The most common size of businesses the respondents worked for or owned were micro enterprises employing less than five employees. A total of $13 \%$ of the respondents indicated the category "Other" regarding the property type, but unfortunately the respondents did not provide specifics. 
S. Barnard

B. Kritzinger

J. Krüger
LOCATION DECISION STRATEGIES FOR IMPROVING SMME BUSINESS PERFORMANCE

Table 2: Demographical data of respondents' businesses

\begin{tabular}{|c|c|c|c|}
\hline \multicolumn{2}{|l|}{ Items } & Frequency & Percentage (\%) \\
\hline \multirow{7}{*}{$\begin{array}{l}\text { Length of employment } \\
\text { (years) }\end{array}$} & $0-2$ & 32 & 18 \\
\hline & $3-5$ & 51 & 29 \\
\hline & $6-9$ & 27 & 15 \\
\hline & $10-19$ & 45 & 26 \\
\hline & $20+$ & 17 & 10 \\
\hline & Missing & 3 & 2 \\
\hline & Total & 175 & 100 \\
\hline \multirow{7}{*}{$\begin{array}{l}\text { Length of business } \\
\text { operation }\end{array}$} & $0-2$ & 21 & 12 \\
\hline & $3-5$ & 40 & 23 \\
\hline & $6-9$ & 26 & 15 \\
\hline & $10-19$ & 46 & 26 \\
\hline & $20+$ & 35 & 20 \\
\hline & Missing & 7 & 4 \\
\hline & Total & 175 & 100 \\
\hline \multirow{3}{*}{ Purchased/Lease } & Purchased & 67 & 38 \\
\hline & Lease & 108 & 62 \\
\hline & Total & 175 & 100 \\
\hline \multirow{7}{*}{ Property type } & Office & 45 & 23 \\
\hline & Retail & 54 & 28 \\
\hline & Wholesale & 8 & 4 \\
\hline & Industrial/Manufacturing & 27 & 14 \\
\hline & Service & 36 & 18 \\
\hline & Other & 26 & 13 \\
\hline & Total & $196^{*}$ & 100 \\
\hline \multirow{4}{*}{ Size of the business } & Micro & 102 & 58 \\
\hline & Small & 62 & 36 \\
\hline & Medium & 11 & 6 \\
\hline & Total & 175 & 100 \\
\hline
\end{tabular}

* Respondents were able to indicate more than one property type thus frequency does not equal the sample size of 175

\section{Occupational level and factor results}

With regard to the respondents' occupational level and the seven factors, indicated in Table 3, manager, owner as well as both manager and owner perceived each factor differently in terms of importance when choosing the ideal business premises. These findings supported the literature discussion that ownermanagers and non-owner managers have different views according to their lifestyles, personal goals and objectives for the business.

With regard to location, as evident in Table 3, $61 \%$ of managers fell into the High group, indicating that they significantly agreed with the items presented to them in the location section of the questionnaire. On the other hand, the owner and both manager and owner fell in to the Average group with $49 \%$ and $59 \%$ respectively. This indicates that the respective respondents had a neutral attitude towards the consideration of the physical location when choosing business premises. 


\section{S. Barnard \\ B. Kritzinger \\ J. Krüger}

LOCATION DECISION STRATEGIES FOR IMPROVING SMME BUSINESS PERFORMANCE

Only $56 \%$ of managers tended to agree with the rental rates items, and $62 \%$ of owners were grouped in the Average category as they had a neutral response to the rental rate factor. In the occupational level both manager and owner was more or less equally divided into the Average and High groups with $44 \%$ and $45 \%$ respectively. This shows that the respective respondents had a neutral attitude towards rental rates and were also equally in agreement with these items. Managers were the only group that fell in the High group (56\%), implying that they agree that rental rates are an important factor to consider.

Table 3: Frequency distribution of occupational level versus factors

\begin{tabular}{|c|c|c|c|c|c|c|c|c|}
\hline \multicolumn{9}{|l|}{ Location } \\
\hline Occupational level & \multicolumn{2}{|c|}{ Low } & \multicolumn{2}{|c|}{ Average } & \multicolumn{2}{|c|}{ High } & \multicolumn{2}{|c|}{ Total } \\
\hline Manager & 2 & $6 \%$ & 12 & $33 \%$ & 22 & $61 \%$ & 36 & $100 \%$ \\
\hline Owner & 6 & $15 \%$ & 19 & $49 \%$ & 14 & $36 \%$ & 39 & $100 \%$ \\
\hline Both manager and owner & 9 & $9 \%$ & 57 & $59 \%$ & 31 & $32 \%$ & 97 & $100 \%$ \\
\hline Total & 17 & $10 \%$ & 88 & $51 \%$ & 67 & $39 \%$ & 172 & $100 \%$ \\
\hline \multicolumn{9}{|l|}{ Rental rates } \\
\hline Occupational level & \multicolumn{2}{|c|}{ Low } & \multicolumn{2}{|c|}{ Average } & \multicolumn{2}{|c|}{ High } & \multicolumn{2}{|c|}{ Total } \\
\hline Manager & 4 & $11 \%$ & 12 & $33 \%$ & 20 & $56 \%$ & 36 & $100 \%$ \\
\hline Owner & 6 & $15 \%$ & 24 & $62 \%$ & 9 & $23 \%$ & 39 & $100 \%$ \\
\hline Both manager and owner & 10 & $10 \%$ & 43 & $44 \%$ & 44 & $45 \%$ & 97 & $100 \%$ \\
\hline Total & 20 & $12 \%$ & 79 & $46 \%$ & 73 & $42 \%$ & 172 & $100 \%$ \\
\hline \multicolumn{9}{|l|}{ Electricity tariffs } \\
\hline Occupational level & \multicolumn{2}{|c|}{ Low } & \multicolumn{2}{|c|}{ Average } & \multicolumn{2}{|c|}{ High } & \multicolumn{2}{|c|}{ Total } \\
\hline Manager & 16 & $44 \%$ & 11 & $31 \%$ & 9 & $25 \%$ & 36 & $100 \%$ \\
\hline Owner & 15 & $38 \%$ & 18 & $46 \%$ & 6 & $15 \%$ & 39 & $99 \% *$ \\
\hline Both manager and owner & 40 & $41 \%$ & 37 & $38 \%$ & 20 & $21 \%$ & 97 & $100 \%$ \\
\hline Total & 71 & $41 \%$ & 66 & $38 \%$ & 35 & $20 \%$ & 172 & $100 \%$ \\
\hline \multicolumn{9}{|l|}{ Employment } \\
\hline Occupational level & \multicolumn{2}{|c|}{ Low } & \multicolumn{2}{|c|}{ Average } & \multicolumn{2}{|c|}{ High } & \multicolumn{2}{|c|}{ Total } \\
\hline Manager & 0 & $0 \%$ & 6 & $17 \%$ & 30 & $83 \%$ & 36 & $100 \%$ \\
\hline Owner & 3 & $8 \%$ & 8 & $21 \%$ & 28 & $72 \%$ & 39 & $101 \%$ * \\
\hline Both manager and owner & 4 & $4 \%$ & 29 & $30 \%$ & 64 & $66 \%$ & 97 & $100 \%$ \\
\hline Total & 7 & $4 \%$ & 43 & $25 \%$ & 122 & $71 \%$ & 172 & $100 \%$ \\
\hline \multicolumn{9}{|l|}{ Inflation } \\
\hline Occupational level & \multicolumn{2}{|c|}{ Low } & \multicolumn{2}{|c|}{ Average } & \multicolumn{2}{|c|}{ High } & \multicolumn{2}{|c|}{ Total } \\
\hline Manager & 1 & $3 \%$ & 5 & $14 \%$ & 30 & $83 \%$ & 36 & $100 \%$ \\
\hline Owner & 2 & $5 \%$ & 14 & $36 \%$ & 23 & $59 \%$ & 39 & $100 \%$ \\
\hline Both manager and owner & 4 & $4 \%$ & 30 & $31 \%$ & 63 & $65 \%$ & 97 & $100 \%$ \\
\hline Total & 7 & $4 \%$ & 49 & $28 \%$ & 116 & $67 \%$ & 172 & $100 \%$ \\
\hline \multicolumn{9}{|l|}{ Interest rates } \\
\hline Occupational level & \multicolumn{2}{|c|}{ Low } & & & Higl & & Tota & \\
\hline Manager & 2 & $6 \%$ & 12 & $33 \%$ & 22 & $61 \%$ & 36 & $100 \%$ \\
\hline Owner & 4 & $10 \%$ & 11 & $28 \%$ & 24 & $62 \%$ & 39 & $100 \%$ \\
\hline Both manager and owner & 12 & $12 \%$ & 38 & $39 \%$ & 47 & $48 \%$ & 97 & $99 \%{ }^{*}$ \\
\hline Total & 18 & $10 \%$ & 61 & $35 \%$ & 93 & $54 \%$ & 172 & $100 \%$ \\
\hline
\end{tabular}




\section{S. Barnard \\ B. Kritzinger \\ J. Krüger}

LOCATION DECISION STRATEGIES FOR IMPROVING SMME BUSINESS PERFORMANCE

\begin{tabular}{|c|c|c|c|c|c|c|c|c|}
\hline \multicolumn{9}{|l|}{ Green buildings } \\
\hline Occupational level & \multicolumn{2}{|c|}{ Low } & \multicolumn{2}{|c|}{ Average } & \multicolumn{2}{|c|}{ High } & \multicolumn{2}{|c|}{ Total } \\
\hline Manager & 0 & $0 \%$ & 7 & $19 \%$ & 29 & $81 \%$ & 36 & $100 \%$ \\
\hline Owner & 3 & $8 \%$ & 12 & $31 \%$ & 24 & $62 \%$ & 39 & $101 \% *$ \\
\hline Both manager and owner & 5 & $5 \%$ & 18 & $19 \%$ & 74 & $76 \%$ & 97 & $100 \%$ \\
\hline Total & 8 & $5 \%$ & 37 & $22 \%$ & 127 & $74 \%$ & 172 & $100 \%$ \\
\hline \multicolumn{9}{|l|}{ Business performance } \\
\hline Occupational level & \multicolumn{2}{|c|}{ Low } & \multicolumn{2}{|c|}{ Average } & \multicolumn{2}{|c|}{ High } & \multicolumn{2}{|c|}{ Total } \\
\hline Manager & 0 & $0 \%$ & 10 & $28 \%$ & 26 & $72 \%$ & 36 & $100 \%$ \\
\hline Owner & 2 & $5 \%$ & 15 & $38 \%$ & 22 & $56 \%$ & 39 & $99 \% *$ \\
\hline Both manager and owner & 5 & $5 \%$ & 27 & $28 \%$ & 65 & $67 \%$ & 97 & $100 \%$ \\
\hline Total & 7 & $4 \%$ & 52 & $30 \%$ & 113 & $66 \%$ & 172 & $100 \%$ \\
\hline
\end{tabular}

* Due to rounding, the percentage does not add up to $100 \%$.

\section{Descriptive statistics}

According to Keller and Warrack (2003:93) and Zikmund (2006:404), the mean is a measure of central tendency and can be calculated by adding all the observations under study and dividing it by the total number of observations. According to Burns and Burns (2008:131), the standard deviation reveals the amount of spread that the scores exhibit around the mean. A mean score of less than 2.60 indicates a negative attitude (strongly disagree and disagree), a score of equal to 2.60 or less than 3.40 indicates a neutral attitude (neutral) and a mean score greater than 3.40 indicates a positive attitude (strongly agree and agree).

From Table 4 it can be seen that employment achieved the highest mean score of 3.73, which implies that the majority of the respondents agreed that employment was a factor (mean > 3.40) to be considered when choosing business premises. The independent variable electricity tariffs received the lowest mean score of 2.75 , indicating that the bulk of the respondents had a neutral attitude $(2.60 \leq$ mean $\leq 3.40)$ with a slight tendency to disagree based on the electricity tariff items presented. In terms of standard deviation, the independent variable electricity tariffs scored the highest score of 0.81 , which means that there was a large distribution around the mean score of 2.75. The independent variable green buildings attained the lowest standard deviation score of 0.59 , implying that there was a small distribution around the mean score of 3.62.

Table 4: Mean, standard deviation and cronbach alpha scores for each factor

\begin{tabular}{|l|l|l|l|l|}
\hline Independent variables & $\mathbf{n}$ & Mean & Standard deviation & Cronbach's $\boldsymbol{\alpha}$ \\
\hline Location & 167 & 3.29 & 0.63 & 0.75 \\
\hline Rental rates & 168 & 3.24 & 0.64 & 0.76 \\
\hline Electricity tariffs & 174 & 2.75 & 0.81 & 0.82 \\
\hline Employment & 173 & 3.73 & 0.64 & 0.85 \\
\hline Inflation & 169 & 3.62 & 0.65 & 0.86 \\
\hline Interest rates & 169 & 3.41 & 0.71 & 0.90 \\
\hline Green buildings & 165 & 3.62 & 0.59 & 0.90 \\
\hline Dependent variable & \multicolumn{5}{|l|}{} \\
\hline Business performance & 168 & 3.65 & 0.84 \\
\hline
\end{tabular}

\section{Internal reliability}

In order to determine the internal reliability of the questionnaire items, the Cronbach Alpha coefficients $(\alpha)$ were calculated. This is in reference to the seven independent variables, namely location, rental rates, electricity tariffs, employment, inflation, interest rates and green buildings, as well as the dependent variable, 


\section{S. Barnard \\ B. Kritzinger \\ J. Krüger}

LOCATION DECISION STRATEGIES FOR IMPROVING SMME BUSINESS PERFORMANCE

business performance. A measuring instrument or item is classified as reliable if the reliability coefficient is equal to or above 0.70 . The greater the Cronbach Alpha coefficients, the greater the internal reliability of the items will be (Hair et al., 2003:172). For the purpose of this study the limit of 0.70 was used. As Table 4 illustrates, all the independent variables and the dependent variable obtained Cronbach Alpha coefficients of above 0.70. More specifically, the independent variables interest rates and green buildings achieved the highest internal reliability scores of 0.90 . The independent variable location obtained the lowest Cronbach Alpha coefficient of 0.75 . It is therefore evident that all the coefficients were greater than the acceptable score of 0.70 and can be considered reliable because they measured what they were set out to measure. In conclusion, all these items were deemed acceptable and used in the data analysis.

\section{Between-factor differences}

As shown in Table 5, the difference noted between the independent variables rental rates and electricity tariffs is not only statistically significant at a $95 \%$ confidence level but also practically significant (Cohen's $d>0.5$ ). Although a statistical difference was observed at a 95\% confidence level between employment and interest rates as well as between interest rates and rental rates, the practical significance was relatively small $(0.2<$ Cohen's $d<0.5)$.

Table 5: Significance of between-factor differences

\begin{tabular}{|c|c|c|c|c|c|c|c|c|}
\hline & & & & & \multicolumn{3}{|c|}{$\begin{array}{l}\text { Matched pair t-test } \\
\text { results }\end{array}$} & \multirow[b]{2}{*}{ Cohen's d } \\
\hline & Mean & Std dev & Diff & Std dev diff & $t$ & df & $p$ & \\
\hline Employment & 3.73 & 0.64 & \multirow[b]{2}{*}{0.11} & \multirow{2}{*}{0.72} & \multirow{2}{*}{1.98} & \multirow[b]{2}{*}{174} & .04 & \multirow{2}{*}{0.15} \\
\hline Inflation & 3.62 & 0.65 & & & & & 9 & \\
\hline Employment & 3.73. & 0.64 & \multirow{2}{*}{0.11} & \multirow{2}{*}{0.68} & \multirow{2}{*}{2.13} & \multirow{2}{*}{173} & .03 & \multirow{2}{*}{0.16} \\
\hline Green buildings & 3.62 & 0.59 & & & & & 4 & \\
\hline Employment & 3.73 & 0.64 & \multirow{2}{*}{0.32} & \multirow{2}{*}{0.82} & \multirow{2}{*}{5.16} & \multirow{2}{*}{173} & .00 & \multirow{2}{*}{0.39} \\
\hline Interest rates & 3.41 & 0.71 & & & & & 0 & \\
\hline Interest rates & 3.41 & 0.71 & \multirow{2}{*}{0.12} & \multirow{2}{*}{0.75} & \multirow{2}{*}{2.21} & \multirow{2}{*}{173} & .02 & \multirow{2}{*}{0.17} \\
\hline Location & 3.29 & 0.63 & & & & & 9 & \\
\hline Interest rates & 3.41 & 0.71 & \multirow[b]{2}{*}{0.17} & \multirow[b]{2}{*}{0.75} & \multirow[b]{2}{*}{2.99} & \multirow[b]{2}{*}{173} & & \multirow[b]{2}{*}{0.23} \\
\hline Rental rates & 3.24 & 0.64 & & & & & 3 & \\
\hline Rental rates & 3.24 & 0.64 & \multirow{2}{*}{0.49} & \multirow{2}{*}{0.89} & \multirow{2}{*}{7.30} & \multirow{2}{*}{174} & .00 & \multirow{2}{*}{0.55} \\
\hline Electricity tariffs & 2.75 & 0.81 & & & & & 0 & \\
\hline
\end{tabular}

With regard to the differences noted between the independent variables employment and inflation, employment and green buildings as well as between interest rates and location, it was only statistically significant at a $95 \%$ confidence level and not practically significant (Cohen's $d<0.2$ ). It is important to note that the between-factor differences for the other variables were neither statistically significant nor practically significant at a $95 \%$ confidence level and are therefore not reported on.

\section{Inferential statistics}

The Pearson correlation coefficient, denoted by the symbol $r$, was calculated in order to establish whether a relationship existed between the independent variables and the dependent variable. Table 6 presents the Pearson correlation coefficient of each of the seven independent variables on the dependent variable, business performance as well as the probability value for each variable. The correlation coefficient was calculated based on a 95\% confidence level. It is evident that a positive relationship existed between the 


\section{S. Barnard \\ B. Kritzinger \\ J. Krüger}

LOCATION DECISION STRATEGIES FOR IMPROVING SMME BUSINESS PERFORMANCE

independent variables location, rental rates, employment, inflation, interest rates and green buildings and the dependent variable, business performance. On the other hand, a negative relationship existed between the independent variable electricity tariffs and business performance.

Table 6: Pearson correlation coefficients, coefficient of determination and probability values of the independent variables

\begin{tabular}{|l|l|l|l|}
\hline Independent variables & $\begin{array}{l}\text { Pearson correlation } \\
\text { coefficients }(\boldsymbol{r})\end{array}$ & $\begin{array}{l}\text { Coefficient of } \\
\text { determination }\end{array}$ & $\left.\boldsymbol{r}^{\mathbf{2}}\right)$ \\
\hline Location & 0.08 & 0.0064 & $\mathbf{p}$-value \\
\hline Rental rates & 0.11 & 0.0128 & 0.40 \\
\hline Electricity tariffs & -0.02 & 0.0003 & 0.63 \\
\hline Employment & $\mathbf{0 . 2 3}$ & 0.0552 & 0.08 \\
\hline Inflation & 0.14 & 0.0254 & $\mathbf{0 . 0 6}$ \\
\hline Interest rates & 0.09 & 0.0074 & 0.19 \\
\hline Green buildings & $\mathbf{0 . 2 1}$ & 0.0458 & 0.94 \\
\hline
\end{tabular}

Employment and business performance attained the strongest positive relationship of 0.23 . This indicates that business owners/managers regarded employment as an important factor to consider when searching for a suitable business premises as it would ultimately influence the performance of the business. The weakest positive relationship existed between location and business performance with a correlation coefficient of 0.08: This implies that business owners/managers also considered the physical location an important factor that influenced their business performance when choosing the ideal business premises, but to a lesser extent.

A relatively weak inverse (negative) relationship existed between electricity tariffs and business performance as it scored -0.02 . This therefore suggests that the greater the value measured by the independent variable, electricity tariffs, the less the value measured by the dependent variable, business performance. The associations between the remaining independent variables and business performance were as follows: Rental rates achieved a score of 0.11 , inflation scored 0.16 , interest rates scored 0.09 and green buildings achieved a score of 0.21 .

The probability value ( $p$-value) was calculated in order to determine the statistical significance of each independent variable in relation to the dependent variable. As can be seen from Table 6 , the following independent variables obtained a p-value greater than the significance level of 0.05: location (0.40), rental rates (0.63), electricity tariffs (0.08), employment (0.06), inflation (0.19) and interest rates (0.94). This indicates that these independent variables were not statistically significant in relation to business performance. Furthermore, the independent variable green buildings obtained a $p$-value of 0.04 . As this value was less than the significance level of 0.05 , it can be stated that it was statistically significant. At a significance level of 0.10 , the independent variable employment is statistically significant as $p<0.10$.

In conclusion, a correlation coefficient of less than zero $(r<0)$ will result in failing to reject the null hypotheses, and a correlation coefficient of greater than zero $(r>0)$ will result in rejecting the null hypotheses. Based on the scores calculated for each independent variable only green buildings was significant at the $5 \%$ significance level. As $r>0$, the null hypothesis for green buildings $\left(H_{0,7}\right)$ was rejected and the researchers failed to reject the alternative hypothesis $\left(\mathrm{H}_{1,7}\right)$. The researchers failed to reject the null hypotheses $\left(\mathrm{H}_{0,1}, \mathrm{H}_{0,2}, \mathrm{H}_{0,3}, \mathrm{H}_{0,5}, \mathrm{H}_{0,6}\right)$ of the remaining independent variables, namely location, rental rates, electricity tariffs, employment, inflation, and interest rates and would reject the alternative hypotheses $\left(\mathrm{H}_{1,1}\right.$, $\left.\mathrm{H}_{1,2}, \mathrm{H}_{1,3}, \mathrm{H}_{1,5}, \mathrm{H}_{1,6}\right)$ because they were not significant $(\mathrm{p}>0.05)$. However, at a $10 \%$ significance level, the 


\section{S. Barnard \\ B. Kritzinger \\ J. Krüger}

LOCATION DECISION STRATEGIES FOR IMPROVING SMME BUSINESS PERFORMANCE

null hypothesis $\left(\mathrm{H}_{0,4}\right)$ of the independent variable employment was also rejected and the researchers failed to reject the alternative hypothesis $\left(H_{1,4}\right)$ since $p<0.10$.

The coefficient of determination $\left(r^{2}\right)$ was used to determine the strength of the relationship between the independent variables and the dependent variable. As can be seen in Table 6, the relationship between employment and business performance achieved the highest coefficient of determination with a value of 0.0552 . This implies that employment was accountable for the highest percentage $(5.52 \%)$ of variance relative to business performance. Therefore, small changes in the employment situation in the business would result in greater improvement in business performance. Electricity tariffs and business performance achieved the weakest relationship with a coefficient of 0.0003 . This indicates that electricity tariffs were accountable for the lowest percentage $(0.03 \%)$ of variance relative to business performance. Therefore minor adjustments in electricity tariffs would contribute the least towards improving business performance.

\section{CONCLUSIONS}

This investigation has provided a concise insight into SMMEs of the Nelson Mandela Metropole. Specifically, the investigation explored the degree to which the predetermined variables (location, rental rates, electricity tariffs, employment, inflation, interest rates and green buildings) influence the dependent variable, business performance, when searching for the ideal business premises. According to the literature, the location of a business plays a significant role in determining whether the business will survive because each location offers different profit potentials.

This study has established that the independent variables green buildings and employment have a positive relationship with the dependent variable business performance. Thus the researchers rejected the null hypotheses $\left(\mathrm{H}_{0,7}, \mathrm{H}_{0,4}\right)$ and failed to reject the alternative hypotheses $\left(\mathrm{H}_{1,7}, \mathrm{H}_{1,4}\right)$. For the remaining independent variables (location, rental rates, electricity tariffs, inflation and interest rates) the researchers failed to reject the null hypotheses $\left(\mathrm{H}_{0,1}, \mathrm{H}_{0,2}, \mathrm{H}_{0,3}, \mathrm{H}_{0,5}, \mathrm{H}_{0,6}\right)$ and rejected the alternative hypotheses $\left(\mathrm{H}_{1,1}\right.$, $\left.\mathrm{H}_{1,2}, \mathrm{H}_{1,3}, \mathrm{H}_{1,5}, \mathrm{H}_{1,6}\right)$. This implies that no relationship existed between these factors and business performance. However, the theoretical findings indicate that all seven macro-environmental factors influence location decisions and hence business performance. Each factor affects location decisions to some degree as aspects within each factor contribute to changes in business performance.

\section{RECOMMENDATIONS}

SMMEs face several challenges that may affect their daily operations and could ultimately lead to business failure if not managed properly. The location of a business can determine whether it will survive in the long run. Therefore, it is imperative that the business owner/manager considers the factors that influence the location decision; these factors include location, rental rates, electricity tariffs, employment, inflation, interest rates and green buildings. Based on the main findings from the literature review and the main findings of the empirical investigation recommendations can be made to assist SMMEs in maximising their potential.

From the empirical findings it can be seen that employment is the most important factor that will influence business performance when searching for a suitable business premises. These findings support the literature on employment in the workplace. Employee satisfaction in the workplace, in terms of the facilities and accessibility, is positively correlated to employee productivity. Thus, if the business site has the necessary facilities in place and complies with the required internal building regulations, business owners can expect an improvement in business performance. For this reason, business owners should pay special attention to employment, especially to adequate rest facilities, proper kitchen and cafeteria facilities, facilities for disabled 


\section{S. Barnard \\ B. Kritzinger \\ J. Krüger}

LOCATION DECISION STRATEGIES FOR IMPROVING SMME BUSINESS PERFORMANCE

employees, adequate medical facilities, satisfactory exit and emergency points as well as allowing for infrastructural changes and easy access for employees.

The relationship between green buildings and business performance was found to be the second most important factor to consider when purchasing or leasing a commercial property. The theory supports the concept that implementing green principles in commercial buildings can significantly save on operating costs for the business. Because of the high initial costs of implementing green principles, it is recommended that businesses, and more specifically SMMEs, search for business premises that already have some green principles in place. This will allow business owners to take advantage of the cost savings and utilise these funds to further implement green principles.

Elements that business owners should consider include naturally ventilated buildings, a centralised airconditioning system, an energy-efficient heating system and equipment, the use of solar heating, tanks for the collection of rain water and sensors that adjust to temperature and light, to mention but a few. The energy-efficiency policy for buildings, the SANS 204 regulation, should also already be adhered to in a building as it will save the business owner time and money when the regulation becomes compulsory for all buildings.

The empirical findings highlight that location had the weakest positive relationship with business performance. This implies that location is an important factor to consider when locating a property, but to a lesser extent than the other macro-environmental factors. This is contradictory to the literature findings relating to location. Based on the theory, location is one of the most important aspects to consider for any business as it has a direct impact on business performance. The nature of a business will mostly determine where the business is located, for example, a boutique shop will not be located in an industrial area as it is not positioned close to the target market.

It is therefore recommended that business owners consider the nature of the business operations, the proximity of suppliers, the accessibility of resources, customer accessibility, the availability of transport facilities for employees, government regulations, the availability of infrastructure and the time required for the owner and the employees to travel from home to the business. Should the business experience rapid growth, the size of the business in terms of the number of employees and in terms of the space required for storing inventory will allow the business to expand without the high costs associated with building renovations.

An important empirical finding is that electricity tariffs had a negative relationship with business performance. This may be due to the fact that the costs associated with electricity, such as tariff hikes, may have a negative impact on profitability, especially for medium-sized enterprises that carry greater electricity costs. In terms of the literature findings, the electrical requirements for each property type and the nature of business activities influence the location decision. For example, industrial businesses require more complex electrical systems than a small clothing shop that only requires basic electrical structures. It is recommended that business owners ensure that a planned programme of inspection and testing be carried out in order to comply with the electrical regulations.

The remaining three macro-environmental factors, namely rental rates, inflation and interest rates, all had a positive relationship with business performance; however, they were not considered as important as the other four factors. Even though they are not as important, they should still be considered when locating a property, and more specifically, when deciding whether to purchase or lease a property.

With regard to rental rates, the rent paid by business owners is seen as an input cost and can have a significant impact on profitability. It is recommended that when searching for a property, business owners 


\section{S. Barnard \\ B. Kritzinger \\ J. Krüger}

take into account the property type, vacancy levels in the geographical area, and the grading and benefits of the building as well as the competitive environment in which the business will operate. In terms of inflation, business owners should take into account the rental amount the business can afford as possible increases in inflation could increase this amount. It is also recommended that business owners consider the interest rate at the time of purchasing a property, as any changes in the prime lending rate will influence the monthly instalment payable.

One of the limitations of the study is that it focused only on SMMEs in Nelson Mandela Bay. Therefore further research is recommended in a wider geographical area as to gain a more general perspective on SMME location decisions and business performance in order to make generalisations. As there are many other macro-environmental factors not investigated in this study that influence the location decisions of business owners, such as transportation, availability of resources and BEE requirements, investigating these additional factors would equip SMME owners with greater knowledge when making location decisions.

To conclude, SMME owners need to be aware of all the factors influencing the location decision. It is recommended that programmes such as the Absa Small Business Enterprise Growth Programme include mentoring on these factors to ensure that an appropriate location is chosen.

\section{REFERENCES}

Abor J \& Quartey P. 2010. Issues in SME development in Ghana and South Africa. International Research Journal of Finance and Economics, (39):218-228.

Ball M, Lizieri C \& MacGregor BD. 2001. The economics of commercial property markets. New York: Routledge.

Berry L. 2010. Electricity supply challenges encourage renewed focus on lighting. Engineering News, 19 February. [Online]. Available: http://www.engineeringnews.co.za/article/electricity-supply-challengesencourage-renewed-focus-on-lighting-2010-02-19 [Accessed 18 November 2010].

Best R, Langston CA \& De Valence G. 2003. Workplace strategies and facilities management. Oxford: Butterworth-Heinemann.

Booty F. 2009. Facilities management handbook. $4^{\text {th }}$ edition. Oxford: Butterworth-Heinemann.

Bosch J, Tait M \& Venter E. 2011. Business management: An entrepreneurial perspective. $2^{\text {nd }}$ edition. Port Elizabeth: Lectern.

Burke G, Clarke L, Molian D \& Barrow P. 2008. Growing your business: A handbook for ambitious ownermanagers. New York: Routledge.

Burns RB \& Burns RA. 2008. Business research methods and statistics using SPSS. London: Sage Publications.

Butler L \& Jack M. 2010. Power-saving vital as Eskom price hike looms. The Herald, 24 April. [Online]. Available: http://www.theherald.co.za/article.aspx?id=555822 [Accessed 23 May 2010].

Campbell T. 2008. The importance of a business location. [Online]. Available: http://ezinearticles.com/?TheImportance-of-a-Business-Location\&id=1075723 [Accessed 15 April 2011]. 


\section{S. Barnard \\ B. Kritzinger \\ J. Krüger}

Cuss EC. 2003. Shop rental growth assessments. Journal of Retail and Leisure Property, 3(3):276.

De Vos AS, Strydom H, Fouché CB \& Delport CSL. 2005. Research at grassroots. $3^{\text {rd }}$ edition. Pretoria: Van Schaik.

Dufaye A. 2005. Know the rules - new trends in electrical testing and inspection. [Online]. Available: http://www.modbs.co.uk/news/fullstory.php/aid/1265/Know_the_rules_97_new_trends_in_electrical_ testing_and_inspection.html [Accessed 18 November 2010].

Ebazaar. 2008. Cause-effect of inflation. [Online]. Available: http://socyberty.com/economics/cause-effect-ofinflation/ [Accessed 18 November 2010].

Elliott R \& Boshoff C. 2007. The influence of the owner-manager of small tourism businesses on the success of internet marketing. South African Journal of Business Management, 38(3)15-27.

Ernst \& Young Summer Survey. 2010. Swiss SMEs eye business opportunities with BRIC countries. SME business barometer 2010, 1 July. [Online]. Available: http://www.ey.com/CH/en/Newsroom/Newsreleases/ [Accessed on 15 April 2011].

Hair JF, Babin B, Money AH \& Samouel P. 2003. Essentials of business research methods. Hoboken, NJ: Wiley.

Hartzell DJ \& Webb RB. 1993. Commercial real estate and inflation during periods of high and low vacancy rates. [Online]. Available: http://www.reri.org/research/abstract_pdf/wp14.pdf [Accessed 9 June 2010].

Heckaman BL. 2008. Cash, cash, cash: What lenders want to see in a commercial property. Real Estate Finance, 25(2):12-14.

'How the interest rate cut' will impact the commercial property market. 2010. [Online]. Available: http://www.commercial-property.co.za/3424_news_How-the-interest-rate-cut-will-impact-thecommercial-property-market.html [Accessed 9 June 2010].

Keller G \& Warrack B. 2003. Statistics for management and economics. $6^{\text {th }}$ edition. Pacific Grove, CA: Thomson.

Kelley DJ, Bosma N \& Amorós JE. 2011. Global Entrepreneurship Monitor 2010 Global Report. [Online]. Available: http://www.gemconsortium.org. [Accessed 5 May 2011].

Kernohan B. 2010. Surprise rate cut expected to boost economy. The Herald, 27 March. [Online]. Available: http://www.theherald.co.za/article.aspx?id=546237 [Accessed 27 March 2010].

Lancaster G. 2005. Research methods in management. Oxford: Elserivier.

Megginson WL, Smart SB \& Graham JR. 2010. Financial management. $3^{\text {rd }}$ edition. Mason, OH: SouthWestern Cencage.

Mungoshi R. 2008. Green building practices urged. [Online]. Available: http://www.joburg.org.za/ content/view/2582/201/ [Accessed 23 May 2010]. 


\section{S. Barnard \\ B. Kritzinger \\ J. Krüger}

Naidoo B. 2008. Energy-efficiency standard likely to become mandatory. Engineering News, 14 November. [Online]. Available: http://www.engineeringnews.co.za/article/energyefficiency-standard-likely-tobecome-mandatory-2008-11-14 [Accessed 8 June 2010].

Olawale F \& Garwe D. 2010. Obstacles to the growth of new SMMEs in South Africa: A principal component analysis approach. African Journal of Business Management, 4(5):729-738.

Perera S \& Baker P. 2007. Performance measurement practices in small and medium size manufacturing enterprises in Australia. Small Enterprise Research, 15(2):10-30.

Petersen N. 2010. South African real estate investor: Commercial handbook. $3^{\text {rd }}$ edition. Cape Town: Real Estate Media.

Roberts J. 2010. Small business failure rate $63 \%$ in the first two years, BusinessLIVE. [Online]. Available: http://www.businesslive.co.za/southafrica/sa_companies/2010/11/16/small-business-failure-rate-63in-first-two-years [Accessed 17 April 2011].

Scarborough NM \& Zimmerer TW. 2003. Effective small business management: An entrepreneurial approach. $7^{\text {th }}$ edition. Upper Saddle River, NJ: Prentice Hall.

Sha S. 2006. An investigation into problems facing small-to-medium sized enterprises in achieving growth in the Eastern Cape: Enhancing the strategy for developing small 'growth potential' firms in the Eastern Cape. [Online]. Available http://eprints.ru.ac.za/288/1/Sha-TR06-146.pdf [Accessed 29 June 2010].

'Small business' development in South Africa. 2009. [Online]. Available: http://www.sbp. org.za/uploads/media/SBP_ALERT_smme_development_in_SA.pdf [Accessed 29 June 2010].

Statistics South Africa. 2006. Changes in standard of living among population groups in South Africa, 1998 - 2006 (Report No. 03-03-02). [Online]. Available: http://www.statssa.gov.za/publications/Report-0303-02/Report-03-03-02.pdf [Accessed 3 May 2011].

Statistics South Africa. 2007. Community Survey, 2007 - Statistical release P0301. [Online]. Available: www.statssa.gov.za/publications/P0301/P0301.pdf [Accessed 3 May 2011].

Struwig FW \& Stead GB. 2001. Planning, designing and reporting research. Cape Town: Pearson.

Vos E \& Roulston C. 2008. SME owner involvement and business performance: Financial security rather than growth. Small Enterprise Research, 16(1):70-85.

Walters S. 2011a. Choosing a retail store location - Important location factors when opening a store. [Online]. Available: http://retail.about.com/od/location/a/selecting_site.htm?p=1 [Accessed 15 April 2011].

Walters S. 2011b. Retail store location important factors - Tips for choosing a location. [Online]. Available: http://retail.about.com/od/location/a/selecting_site_2.htm?p=1 [Accessed 15 April 2011].

Zikmund WG. 2006. Business research methods. $7^{\text {th }}$ edition. Mason, $\mathrm{OH}$ : South Western. 